\title{
Tumour suppressor gene methylation and renal cell carcinoma risk: a comprehensively systematic review and meta-analysis
}

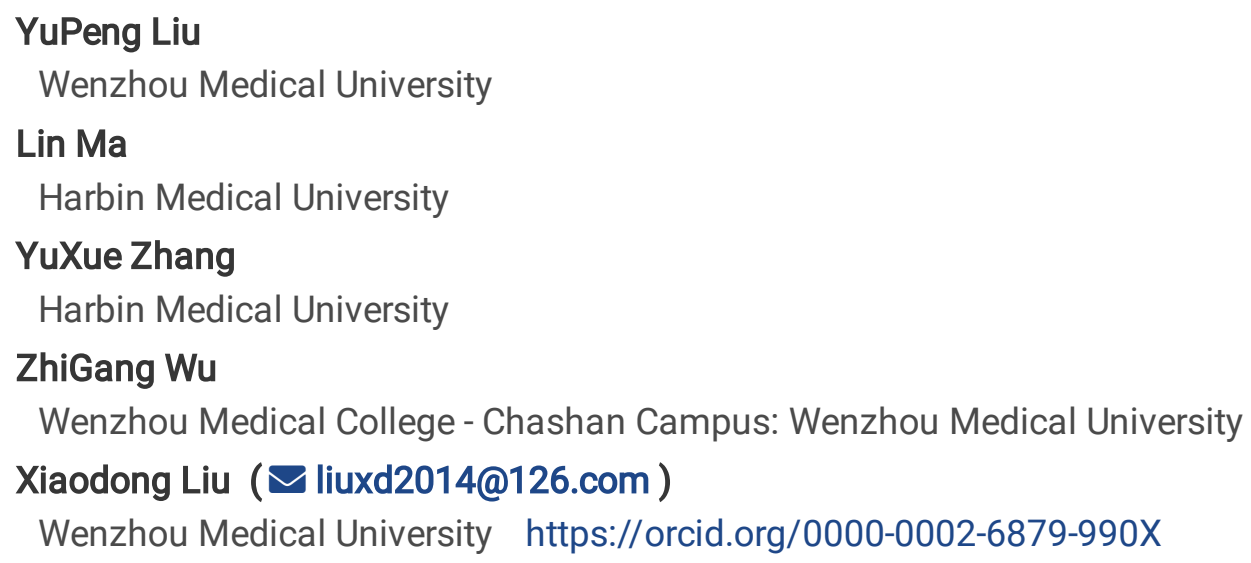

\section{Research}

Keywords: Kidney neoplasms, tumor suppressor genes, methylation, meta-analysis

Posted Date: April 1st, 2021

DOI: https://doi.org/10.21203/rs.3.rs-367957/v1

License: @ (i) This work is licensed under a Creative Commons Attribution 4.0 International License. Read Full License 


\section{Abstract}

Purpose: Renal cell carcinoma (RCC) is becoming more common as a urinary system malignancy. There is a growing body of evidence supporting an important role of DNA methylation alteration involved in the initiation of RCC, but the current findings are inconsistent and controversial. Thus, we performed this systematic review and meta-analysis to comprehensively assess the associations between methylation status of tumour suppressor genes and the incidence risk of RCC.

Methods: This study has been registered on PROSPERO (CRD42019130782) and was reported according to the PRISMA guidelines. We systematically searched the PubMed, EMBASE and CNKI databases for relevant studies. The effect estimates were summarized using random-effect models.

Results: A total of 21 case-control studies containing 1,912 participants were included. Overall, abnormal hypermethylation of RASSF1A was associated with a significantly increased risk of RCC $(\mathrm{OR}, 6.612,95 \%$ Cl: 1.926 $22.697, P=0.003)$, especially in the American populations (OR, $18.429,95 \% \mathrm{Cl}: 3.072-110.536, P=0.001)$. An increased RCC risk was also associated with hypermethylation of SFRP1 and GSTP1 (OR, 3.995, 95\% Cl: 1.607-9.934, $P=0.003$; OR, 4.508, 95\% Cl: 1.004-20.239, $P=0.049$; respectively); however, the results for SFRP1 and GSTP1 were non-conclusive due to the limited number of studies included and the inconsistency across sensitivity analyses. There was no obvious association for the other genes.

Conclusion: This study demonstrated a statistically and robustly positive association of aberrant hypermethylation of RASSF1A with an increased risk of developing RCC, indicating a potentially useful biomarker to predict the RCC incidence risk.

\section{Introduction}

According to the data from GLOBOCAN 2018, a total of approximately 431,288 kidney cancer patients were newly diagnosed and 179,368 deaths from the disease in 2020 worldwide.(1, 2) More importantly, unlike most other tumours, the incidence of kidney cancer has shown a significant upward trend around the world: from 1990 to 2013 , the incidence has increased by $36 \%$ and $34 \%$ in developed and developing countries, respectively. $(3,4)$ In the United States, the incidence of the disease has been increasing at an annual growth rate of about $2 \sim 3 \%$; while the growth rate in China was much higher than that in the United States. $(2,5)$ In China, the estimated incidence and mortality of kidney cancer reached 73,587 and 43,196 in 2020 , respectively.(2)

Renal cell carcinoma (RCC) accounts for approximately $90 \%$ of kidney carcinogenesis, which is by far one of the most common types of urinary system malignancies and poses considerable risks to human health.(3) The disease is histopathologically diverse, comprising several main subtypes, including clear cell RCC (ccRCC, 75-80\%), papillary RCC (pRCC, 10-15\%), and chromophobe RCC (chRCC, 5\%), and other unusual forms, such as collecting duct carcinoma (< $1 \%)$, constitute the remainder. Early-stage renal cell tumours usually maintain silent growth and form until the point where clinical manifestations that are often non-specific and misattributed emerge, resulting in a batch of patients that are found at a more advanced stage where metastases and dissemination have already arisen at diagnosis confounded by the lack of novel techniques for earlier detection. $(3,6)$

With the advent of the molecular medicine epoch, aberrant epigenetic alterations, a hallmark of cancer, have been widely conceived as a chief component of renal tumourigenesis. DNA methylation, a covalent chemical modification, functions as a regulator of gene expression. The list of tumour suppressor genes (TSGs) hampered by hypermethylation of promoter regions, especially those associated with partial or complete transcriptional silencing, has recently increased, which provides an opportunity for us to gain insight into the widespread role of gene methylation in RCC. $(7,8)$ TSGs are 
genes that protect cells from uncontrolled growth fostering tumour development. It is far beyond dispute that the loss or abatement of their effects will result in transcriptional repression and silencing in malignant tumours, including RCC.(9) Given these circumstances, it is a particularly important point to consider that aberrant gene methylation is valuable in RCC progression and diagnoses. Recently, a substantial volume of published studies has attempted to evaluate the epigenetic alteration in RCC, but the findings are inconsistent and controversial. Consequently, we endeavoured to initiate a general meta-analysis with eligible literature for the sake of integrated illumination of the relationship between abnormal DNA methylation and the potential risk of RCC.

\section{Material And Methods}

\subsection{Retrieval strategy}

This study was registered on PROSPERO (CRD42019130782)(10) and was reported according to the Preferred Reporting Items for Systematic Reviews and Meta-Analyses (PRISMA) guidelines (the PRISMA checklist is provided as Appendix A).(11) A thorough search was systematically conducted utilizing the databases of PubMed, EMBASE and CNKI for relevant studies published prior to January 8, 2020. The details of the corresponding combination of MeSH Terms and free words used in the search are provided in Supplementary Information. When studies did not report sufficient data to calculate the effect estimates, we contacted authors for supplement relevant data. Finally, in a manually manner, the reference lists of included studies were scrutinized for potentially relevant studies.

\subsection{Inclusion criteria of eligible studies}

Studies included in the meta-analysis met the following inclusion criteria: (1) original researches focused on the associations between aberrant gene methylation and RCC risk; (2) case-control or cohort studies; (3) reported sufficient data to calculate relative risk ratios (RR) or odds ratios (ORs) and corresponding 95\% confidential intervals (Cls); (4) studies derived samples from tissues of patients and controls; (5) when the results from the same cohort were reported more than once, the latest dataset with a longer follow-up period were included; and (6) there were no restrictions on language.

\subsection{Exclusion criteria}

The exclusion criteria included the following: (1) mechanism studies, e.g. animal model studies, and studies using cell lines; (2) reviews, meta-analyses, and conference abstracts; (4) the samples of studies were obtained from benign tumours, such as oncocytoma (a subtype of kidney neoplasm); (5) studies specializing in Wilm's tumour (kidney tumour of paediatric patients); and (6) studies with a sample size of less than 10.

\subsection{Literature screening}

According to the predesigned retrieval protocol, literatures were independently screened by two investigators (YPL and LM). Discrepancies were solved through consultation by another reviewer (YXZ). Primarily, we looked through each available study whose title and abstracts were in accordance with the retrieval terms. If the title and abstract fit the criteria, we continued to intensively read them in full. Then, we collected and classified genes investigated at least three studies that focused on the relationship between methylation level and RCC risk. Eventually, eligible studies focused on RASSF1A $(\mathrm{n}=14), \operatorname{SFRP1}(\mathrm{n}=5), \operatorname{TIMP3}(\mathrm{n}=5), \operatorname{APC}(\mathrm{n}=4), \operatorname{CDH1}(\mathrm{n}=4), \operatorname{GSTP1}(\mathrm{n}=3), \operatorname{MGMT}(\mathrm{n}=3), \operatorname{RAR} \beta 2(\mathrm{n}=3)$ and $p 16(\mathrm{n}=3)$ were included in the final meta-analysis.

\subsection{Data extraction and quality assessment}

Relevant data were extracted independently by two co-authors (YPL and LM) using a predesigned standardized data extraction tool. These data comprised first author, publication year, country, sample type, sample size, pathological subtypes, and methods of methylation detection. The quality of individual studies was assessed with the Newcastle- 
Ottawa Quality Assessment Scale (NOS), which consists of three components, including selection, comparability and exposure biases.(12)

\subsection{Statistical analysis}

All statistical analyses were conducted with the Comprehensive Meta Analysis software (Version 2.0.1; Biostat, Englewood, NJ, USA). The summarized effect estimates were reported as pooled ORs with corresponding $95 \% \mathrm{Cls}$. The $R$ and Q-tests were used to evaluate the between-study heterogeneity, and $R$ and $P$-values were reported. If the OR was greater than 1.00 and the $P$-value was less than 0.05 , abnormal methylation significantly increased the incidence risk of RCC. Given various populations and methods of methylation assessment involved in these original researches, we preferentially adopted random-effect models to summarize the effect estimates in a conservative manner; while fixedeffect models were used for sensitivity analyses. Potential publication bias was evaluated by the two-sided Egger's regression test and Begg's test, and was further examined through observing symmetry of the funnel plots. Additionally, to be conservative, we rigorously used the Duval and Tweedie's trim-and-fill method to control for the potential bias.

\subsection{Sensitivity analysis}

We performed extensive sensitivity analyses to assess the robustness of the results. We summarized the effect estimates using fixed-effect models and assessed the consistency of the summarized results between fixed and random-effect models. Then, a sensitivity analysis was implemented by omitting each included study to determine whether it had an impact on the results. Furthermore, to investigate whether the potential residual confounders could affect the significant outcome, we calculated the E-value analysis.(13) Theoretically, a larger E-value demonstrates a more robust and stable result. Furthermore, as regards $R A S S F 1 A$ and $S F R P 1$, several post hoc sensitivity analyses, including meta-regression on sample size and cumulative meta-analyses on publication year, quality assessment score and sample size, were performed to validate the statistical stability of our results. Specifically, as regards RASSF1A, additional sensitivity analyses, stratified subgroup analyses by countries, pathological subtypes and clinical stages were also performed.

\section{Results}

\subsection{Study identification and quality assessment}

The detailed systematic search procedure based on the retrieval strategy was shown in Fig. 1. A total of 21 case-control studies involving 1,912 participants (1201 cases and 711 cancer-free controls) were finally included in this present meta-analysis.(14-34) All these articles were published from 2001 to 2018 . The sample size ranged from 20 to 291 , with a median of 83 subjects. Overall, the study quality was high with $71 \%(15 / 21)$ studies categorized as high quality ( $\geq 7$ NOS score). The main characteristics of included studies were provided in Table 1 and the detailed quality scores of domains of included studies were shown in Table S1 in the Supplementary Information. 
Table 1

Characteristics of case-control studies included in this meta-analysis.

\begin{tabular}{|c|c|c|c|c|c|c|c|c|}
\hline Study & $\begin{array}{l}\text { Publication } \\
\text { Year }\end{array}$ & Country & $\begin{array}{l}\text { No. } \\
\text { of } \\
\text { Case }\end{array}$ & $\begin{array}{l}\text { No. of } \\
\text { Control }\end{array}$ & $\begin{array}{l}\text { Pathological } \\
\text { Subtypes }\end{array}$ & Genes & $\begin{array}{l}\text { Methylation } \\
\text { detection } \\
\text { method }\end{array}$ & $\begin{array}{l}\text { Quality } \\
\text { Score } \\
\text { (NOS) }\end{array}$ \\
\hline Yoon JH & 2001 & America & 32 & 10 & RCC & RASSF1A & MSP & 6 \\
\hline $\begin{array}{l}\text { Dreijerink } \\
\mathrm{K}\end{array}$ & 2001 & America & 43 & 29 & $\mathrm{ccRCC}$ & RASSF1A & MSP & 5 \\
\hline $\begin{array}{l}\text { Morrissey } \\
\text { C }\end{array}$ & 2001 & $\begin{array}{l}\text { United } \\
\text { Kingdom }\end{array}$ & 211 & 80 & $\begin{array}{l}\text { ccRCC, } \\
\text { pRCC }\end{array}$ & RASSF1A & MSP & 7 \\
\hline Cairns P & 2003 & America & 47 & 10 & RCC & RASSF1A & MSP & 4 \\
\hline $\begin{array}{l}\text { Gonzalgo } \\
\text { ML }\end{array}$ & 2004 & America & 30 & 22 & $\begin{array}{l}\text { ccRCC, } \\
\text { pRCC }\end{array}$ & RASSF1A & QMSP & 8 \\
\hline Loginov VI & 2004 & Russia & 53 & 30 & RCC & RASSF1A & MSR & 7 \\
\hline $\begin{array}{l}\text { Tokinaga } \\
\text { K }\end{array}$ & 2004 & Japan & 50 & 39 & ccRCC & RASSF1A & COBR & 7 \\
\hline Dulaimi E & 2004 & America & 92 & 10 & $\begin{array}{l}\text { ccRCC, } \\
\text { pRCC, } \\
\text { chRCC, } \\
\text { Collecting } \\
\text { duct, RCC } \\
\text { unclassified, } \\
\text { TCC renal } \\
\text { pelvis }\end{array}$ & $\begin{array}{l}\text { RASSF1A, } \\
\text { TIMP3, } \\
\text { APC, } \\
\text { CDH1, } \\
\text { GSTP1, } \\
\text { MGMT, } \\
\text { RARß2, } \\
\text { p16 }\end{array}$ & MSP & 8 \\
\hline Duan JM & 2007 & China & 26 & 26 & Unasserted & RASSF1A & MSP & 7 \\
\hline Peters I & 2007 & Germany & 45 & 45 & ccRCC & RASSF1A & COBRA & 6 \\
\hline Costa VL & 2007 & Portugal & 75 & 62 & $\begin{array}{l}\text { ccRCC, } \\
\text { pRCC, } \\
\text { chRCC }\end{array}$ & $\begin{array}{l}\text { RASSF1A, } \\
\text { TIMP3, } \\
\text { CDH1, } \\
\text { APC, } \\
\text { GSTP1, } \\
\text { MGMT, } \\
\text { RARB2, } \\
\text { p16 }\end{array}$ & QMSP & 7 \\
\hline Gumz ML & 2007 & America & 10 & 10 & ccRCC & SFRP1 & MSP & 6 \\
\hline Awakura Y & 2008 & Japan & 65 & 22 & $\begin{array}{l}\text { ccRCC, } \\
\text { pRCC }\end{array}$ & SFRP1 & MSP & 8 \\
\hline Zhang JY & 2008 & China & 12 & 12 & RCC & RASSF1A & MSP & 6 \\
\hline Onay H & 2008 & Turkey & 21 & 21 & RCC & $\begin{array}{l}\text { RASSF1A, } \\
\text { TIMP3, } \\
A P C, \\
M G M T, \\
R A R \beta 2, \\
p 16\end{array}$ & MSP & 8 \\
\hline Yin FC & 2010 & Germany & 32 & 15 & pRCC & SFRP1 & QMSP & 8 \\
\hline Zheng FF & 2010 & China & 53 & 53 & $\mathrm{RCC}$ & TIMP3 & MSP & 8 \\
\hline
\end{tabular}




\begin{tabular}{|lllllllll|}
\hline Study & $\begin{array}{l}\text { Publication } \\
\text { Year }\end{array}$ & Country & $\begin{array}{l}\text { No. } \\
\text { of } \\
\text { Case }\end{array}$ & $\begin{array}{l}\text { No. of } \\
\text { Control }\end{array}$ & $\begin{array}{l}\text { Pathological } \\
\text { Subtypes }\end{array}$ & Genes & $\begin{array}{l}\text { Methylation } \\
\text { detection } \\
\text { method }\end{array}$ & $\begin{array}{l}\text { Quality } \\
\text { Score } \\
\text { (NOS) }\end{array}$ \\
\hline Ellinger J & 2010 & China & 66 & 30 & RCC & $\begin{array}{l}\text { RASSF1A, } \\
\text { TIMP3, } \\
\text { APC, } \\
\text { CDH1, } \\
\text { GSTP1 }\end{array}$ & 9 \\
\hline $\begin{array}{l}\text { Atschekzei } \\
\text { F }\end{array}$ & 2012 & China & 20 & 3 & RCC & SFRP1 & MSP & 7 \\
\hline Liu B & 2012 & Germany & 96 & 120 & RCC & CDH1 & Pyrosequencing & 8 \\
\hline Yin FC & 2018 & China & 122 & 62 & CCRCC & SFRP1 & MSP & 8 \\
\hline
\end{tabular}

\subsection{Association between aberrant gene methylation and RCC risk}

The associations between the methylation status of all nine TSGs and the risk of RCC were shown in Fig. 2. Overall, RASSF1A hypermethylation contributed significantly to an increased risk of RCC (OR, 6.612, 95\% Cl: 1.926-22.697, $P=$ 0.003 ) with an obvious between-study heterogeneity $(R=78.11 \%, P<0.001)$, however subgroup analyses by pathological subtypes showed no statistically significant associations for ccRCC or pRCC (Fig. 3). Notably, subgroup analyses by countries showed this positive association was restricted to American populations (OR, 18.429, 95\% Cl: 3.072-110.536, $P=0.001$ ) but not Asian or European populations. SFRP1 hypermethylation also contributed to an significantly increased risk of RCC (OR, 3.995, 95\% Cl: 1.607-9.934, $P=0.003)$ with an obvious between-study heterogeneity $(R=85.26 \%, P<0.001)$. GSTP1 hypermethylation had a marginally significant association with an increased RCC risk (OR, 4.508, 95\% Cl: 1.004-20.239, $P=0.049)$ with no heterogeneity across studies $(R=0.00 \%, P=$ 0.815). Meanwhile, the associations for other remaining genes did not reach statistical significance.

\subsection{Sensitivity analysis}

Sensitivity analyses using fixed effect models showed no materially changed results with the exception of SFRP1 (Table 2). The E-value sensitivity analysis for point estimates and lower $\mathrm{Cl}$ limits also denoted robust results for RASSF1A and SFRP1, but not for GSTP1 (Table 3). Additional analyses by omitting the included studies one by one demonstrated a relative robustness of the results of our present meta-analysis (Figure S1). Finally, cumulative metaanalysis of publication year, quality assessment score and sample size also validated our robust results (Figure $\mathbf{S 2}$ and S3). 
Table 2

Sensitivity analyses using fixed effect models.

\begin{tabular}{|c|c|c|c|c|c|}
\hline \multirow[t]{2}{*}{ Genes } & \multirow[t]{2}{*}{ Models } & \multicolumn{3}{|c|}{ Pooled ORs and $95 \% \mathrm{Cls}$} & \multirow{2}{*}{$\begin{array}{l}\text { P-value } \\
\text { for between models }\end{array}$} \\
\hline & & Point estimate & Lower limit & Upper limit & \\
\hline \multirow[t]{2}{*}{ RASSF1A } & Fixed & 7.593 & 4.395 & 13.116 & \multirow[t]{2}{*}{0.841} \\
\hline & Random & 6.612 & 1.926 & 22.697 & \\
\hline \multirow[t]{2}{*}{ SFRP1 } & Fixed & 1.391 & 1.251 & 1.545 & \multirow[t]{2}{*}{0.024} \\
\hline & Random & 3.995 & 1.607 & 9.934 & \\
\hline \multirow[t]{2}{*}{ TIMP3 } & Fixed & 1.260 & 0.631 & 2.517 & \multirow[t]{2}{*}{0.308} \\
\hline & Random & 2.896 & 0.685 & 12.240 & \\
\hline \multirow[t]{2}{*}{$A P C$} & Fixed & 2.052 & 0.837 & 5.031 & \multirow[t]{2}{*}{1.000} \\
\hline & Random & 2.052 & 0.837 & 5.031 & \\
\hline \multirow[t]{2}{*}{$\mathrm{CDH1}$} & Fixed & 2.121 & 1.151 & 3.908 & \multirow[t]{2}{*}{0.825} \\
\hline & Random & 2.745 & 0.303 & 24.873 & \\
\hline \multirow[t]{2}{*}{ GSTP1 } & Fixed & 4.508 & 1.004 & 20.239 & \multirow[t]{2}{*}{1.000} \\
\hline & Random & 4.508 & 1.004 & 20.239 & \\
\hline \multirow[t]{2}{*}{$M G M T$} & Fixed & 0.769 & 0.240 & 2.467 & \multirow[t]{2}{*}{0.913} \\
\hline & Random & 0.679 & 0.099 & 4.650 & \\
\hline \multirow[t]{2}{*}{$R A R \beta 2$} & Fixed & 1.232 & 0.296 & 5.126 & \multirow[t]{2}{*}{1.000} \\
\hline & Random & 1.232 & 0.296 & 5.126 & \\
\hline \multirow[t]{2}{*}{ p16 } & Fixed & 1.968 & 0.669 & 5.787 & \multirow[t]{2}{*}{1.000} \\
\hline & Random & 1.968 & 0.669 & 5.787 & \\
\hline
\end{tabular}

Table 3

E-value analyses for pooled effect estimates.

\begin{tabular}{|llll|}
\hline Genes & Pooled OR, 95\%Cl & E-value for & \\
\cline { 3 - 4 } & & Point estimate & Lower Cl limit \\
\hline RASSF1A & $6.612(1.926-22.697)$ & 12.7035 & 3.2615 \\
\hline SFRP1 & $3.995(1.607-9.934)$ & 7.454 & 2.5946 \\
\hline GSTP1 & $4.508(1.004-20.239)$ & 8.4847 & 1.0674 \\
\hline
\end{tabular}

\subsection{Publication bias exploration}

Overall, there was no obvious evidence of overt publication bias by using funnel plots (Figure S4), Begg's test or Egger's test (Table S2). For SFRP1, however, there seemed to be a obvious publication bias based on Egger's test $(P=0.006)$. We 
conservatively tacked extra virtual studies using the Duval and Tweedie's trim-and-fill method, and found no significant change of the results, suggesting there was no publication bias in this study and the present results were very robust. For SFRP1, similarly, the pooled OR after trim-and-fill adjustment did not reach statistical significance $(\mathrm{OR}, 1.478,95 \% \mathrm{Cl}$ : $0.631-3.462)$, implicating a potential publication bias.

\section{Discussion}

Our present study comprehensively clarified the associations of a total of nine TSGs methylation status with the risk of RCC. Specifically, eight of them (except RASSF1A) were summarized using meta-analysis for the first time. Overall, our data demonstrated that abnormal RASSF1A and SFRP1 hypermethylation significantly increased the risk of RCC and that the association between aberrant GSTP1 hypermethylation and RCC risk was marginally significant. However, the associations for TIMP3, APC, CDH1, MGMT, RARß2 and $p 16$ did not reach statistical significance.

With respect to RASSF1A, our results were in accordance with the findings from two previous meta-analyses. $(35,36)$ It is noteworthy that a significantly increased risk of RCC related with RASSF1A hypermethylation was observed only in the American subpopulation. In view of the histopathological subtypes, this positive association diminished to a borderline significance for pRCC and non-significance for ccRCC. All these results from subgroup analyses are needed to be validated in future studies. With respect to SFRP1 and GSTP1, sensitivity analyses suggested that no confirm conclusion could be drawn, even though the primary analyses showed a trend of positive association.

In recent reports, TSGs were reported to play vital roles in the epigenetic inactivation by hypermethylation. For example, epigenetic silencing of the longer isoform of Ras-association domain family (RASSF1A), a tumour suppressor gene located at 3p21.3, is specifically associated with cancer.(16) The multifaceted functions of RASSF1A involve cell cycle control, microtubule stabilization, cellular adhesion, motility and regulation of apoptosis.(22) Hypermethylation of the CpG Island in the RASSF1A promoter observed in RCC patients leads to transcriptional downregulation of its mRNA.(15) In addition, RASSF1A methylation, which is rarer in normal tissues than in tumour tissues, provides high specificity and often gives rise to advanced tumour stage and grade, metastasis, poor tumour differentiation and adverse survival.(8, 37) SFRP1 lies at 8p11.2 as an inhibitor of Wnt signalling and acts as a tumour suppressor involved in the control of cellular growth and neovascularization. $(38,39)$ A tumorigenic role of methylation-induced epigenetic silencing has been confirmed as the most likely mechanism responsible for the common event of SFRP1 repression in RCC. $(24,25,40)$ GSTP1, on chromosome 11q13-qter, occupies a vital position in cell survival and proliferation in growth-limiting conditions, mediating MEK/ERK-dependent cell cycle progression and preventing cell cycle arrest.(41) A consequence of decreased expression of GSTP1 by hypermethylation may render cells vulnerable to apoptosis as well as genome damage and may be involved in early tumourigenesis.(42) Of all the factors, observing a tendency for in-depth explorations in our knowledge of epigenetic mechanisms, the essentiality of aberrant DNA methylation, has been further highlighted, which affects the initiation and progression of kidney cancers.

Aberrant methylation of TSGs might be a relatively early event in renal tumourigenesis that is mostly observed in tumours of the lowest pathological stages and grades as well as tumours $<3 \mathrm{~cm}$ in diameter.(21) Therefore, the earlier test of hypermethylation of specific TSGs among renal tumours can be conducive to clinical application related to differential diagnosis, targeted treatment and evaluating molecular prognosis, which can be used to interfere with the carcinogenesis of RCC aimed at reversing silence or their downstream inactivation of certain genes. In addition, precise timing of gene hypermethylation of individuals might help clinicians predict the behaviour or pathological stage of developing tumours. Therefore, accurately extended examinations are indispensable in addressing the problem of harbouring suspicious masses in patients' kidneys. It is necessary for further studies to provide insight into the disease through larger scale studies to dissect out the role of methylated genes and confirm the feasibility of our hypothesis. 
Our study established a basic foundation for progress in a stationary field and will aid in finding more effective therapies for RCC.

As an advantage of this present meta-analysis, we performed extensive sensitivity analyses. To date, the E-value analysis in meta-analyses has not been utilized widely. With the intention to produce evidence for causality, it is suggested to calculate the E-value for both the observed association estimate and the limit of the confidence interval closest to the null value. If the association is not strong, the E-value will be quite small. The robustness to unmeasured confounding as well as the evidence for causality thus might be weak but does not imply evidence is absent. As a consequence, our study was proven to be relatively robust and was unlikely to be affected by potential unmeasured confounders. Other sensitivity analyses, including fixed-effect models, omitting each individual study, meta-regression analyses, and cumulative meta-analyses, also showed a consistency between results, suggesting robust results in our study.

This present study had some limitations. Firstly, the existing heterogeneity across studies was obvious. We performed meta-regression and subgroup analyses to explore potential sources of the heterogeneity and only found the sample size of individual studies may be a possible source of the heterogeneity across studies for SFRP1 (Figure S5). In addition, we cannot overlook the divers methods used to determine the methylation status in tumour tissue samples. In these included studies, the DNA methylation status was mostly examined by MSP, COBRA and QMSP. Their natural sensitivity and specificity may give rise to latent heterogeneity. It was no wonder that the between-study heterogeneity was obvious given various detection methods. In addition, not all methylation in tumour cells contributes to gene silencing, and the presence of expression is largely dependent on the degree of methylation in the cell lines. Another limitation is residual confounders in original studies, even though the E-value analyses showed limited evidence for unmeasured confounding biases in this meta-analysis. Given the limited number of eligible studies for each individual gene and obvious heterogeneity across studies due to various detection methods, future researches with large sample size are required.

\section{Conclusions}

This present meta-analysis revealed a statistically and robustly significant association of aberrant hypermethylation of RASSF1A with the risk of developing RCC, indicating a potentially useful biomarker to predict the incidence risk of RCC. For the other TSGs, no firm conclusion could be drawn. Admittedly, our findings should be affirmed by future welldesigned studies with larger sample sizes.

\section{Abbreviations}

ccRCC, clear cell renal cell carcinoma; chRCCs, chromophobe renal cell carcinoma; Cl, 95\% confidential interval; COBRA, combined bisulfite restriction analysis; MSP, Methylation-specific polymerase chain reaction; MSRA, PCR-based methylation-sensitive restriction enzyme analysis; OR, odds ratio; 95\% pRCC, papillary renal cell carcinoma; QMSP, quantitative methylation-specific polymerase chain reaction; RCC, Renal cell carcinoma; TSG, tumor suppressor gene.

\section{Declarations}

Funding: This work was supported by the Natural Science Foundation of Heilongjiang Province (YQ2019H021 to YPL); the China Postdoctoral Science Foundation (2018M641875 to YPL); the Basic Medical and Health Science Project of Wenzhou Science and Technology Bureau (Y20190191 to YPL); and the National Key Research and Development Program of China (2017YFC0108602 to XDL). The funders and sponsors had no role in the design and conduct of the 
study; collection, management, analysis, and interpretation of the data; preparation, review, or approval of the manuscript; and decision to submit the manuscript for publication.

Conflicts of interests: None.

Availability of data and material: All the data extracted from original studies used in the present study are provided in the main text and supplementary information, any other relevant data are available from the corresponding author upon request.

Code availability: Not applicable.

Authors' Contributors: YPL and XDL conceived the study and designed the protocol. YPL, LM and YXZ did the literature search, extracted data, and quality assessment. YPL, LM and YXZ analyzed the data and created figures. All authors contributed to data analysis and interpretation. YPL, LM and YXZ wrote the first draft of the manuscript; YXZ, ZGW and XDL participated in the critical revision of the manuscript. XDL were responsible for interpretation of the data and critical revision of the manuscript, and had full access to the pooled data and final responsibility for the decision to submit for publication. All authors read and approve the final manuscript. The corresponding author attests that all listed authors meet authorship criteria and that no others meeting the criteria have been omitted.

Ethics approval: Not applicable.

Consent to participate: Not applicable.

Consent for publication: Not applicable.

Acknowledgements: We are grateful to the researchers and participants in the individual studies included in our present meta-analysis.

\section{References}

1. Bray F, Ferlay J, Soerjomataram I, Siegel RL, Torre LA, Jemal A. Global cancer statistics 2018: GLOBOCAN estimates of incidence and mortality worldwide for 36 cancers in 185 countries. Cancer J Clin. 2018;68(6):394-424. doi 10.3322/caac.21492.

2. Ferlay J, Ervik M, Lam F, Colombet M, Mery L, Piñeros M, Znaor A, Soerjomataram I, Bray F. (2018). Global Cancer Observatory: Cancer Today. Lyon, France: International Agency for Research on Cancer. https://gco.iarc.fr/today/home (Accessed April 7, 2020).

3. Capitanio U, Bensalah K, Bex A, Boorjian SA, Bray F, Coleman J, et al. Epidemiology of Renal Cell Carcinoma European urology. 2019;75(1):74-84. doi 10.1016/j.eururo.2018.08.036.

4. Dy GW, Gore JL, Forouzanfar MH, Naghavi M, Fitzmaurice C. Global Burden of Urologic Cancers, 1990-2013. European urology. 2017;71(3):437-46. doi 10.1016/j.eururo.2016.10.008.

5. Moch H, Lash LH, Scelo G: Kidney cancer, in Stewart BW and Wild CP, editors: World Cancer Report 2014. Lyon, France, International Agency for Research on Cancer, World Health Organization 2014:632 - 44.

6. Capitanio U, Montorsi F. Renal cancer. Lancet. 2016;387(10021):894-906. doi 10.1016/S0140-6736(15)00046-X.

7. $\mathrm{Ng} \mathrm{JM}, \mathrm{Yu}$ J. Promoter hypermethylation of tumour suppressor genes as potential biomarkers in colorectal cancer. Int J Mol Sci. 2015;16(2):2472-96. doi 10.3390/ijms16022472.

8. Shenoy N, Vallumsetla N, Zou Y, Galeas JN, Shrivastava M, Hu C, et al. Role of DNA methylation in renal cell carcinoma. J Hematol Oncol. 2015;8:88. doi 10.1186/s13045-015-0180-y. 
9. Xing $\mathrm{T}, \mathrm{He} \mathrm{H}$. Epigenomics of clear cell renal cell carcinoma: mechanisms and potential use in molecular pathology. Chinese journal of cancer research = Chung-kuo yen cheng yen chiu. 2016;28(1):80-91. doi 10.3978/j.issn.10009604.2016.02.09.

10. Liu YP, Ma L, Zhang YX, Du C, Liu XD. DNA methylation of tumor suppressor genes and renal cell carcinoma risk: a systematic review and meta-analysis. https://www.crd.york.ac.uk/prospero/display_record.php?RecordID=130782. (Accessed Nov 22, 2020).

11. Moher D, Liberati A, Tetzlaff J, Altman DG, Group P. Preferred reporting items for systematic reviews and metaanalyses: the PRISMA statement. Ann Intern Med. 2009;151(4):264-9. doi 10.7326/0003-4819-151-4-20090818000135. W64.

12. Wells GA, Shea B, O'Connell D, Peterson J, Welch V, Losos M, et al. The Newcastle -Ottawa Scale (NOS) for assessing the quality if nonrandomized studies in meta-analyses. Available:

http://www.ohri.ca/programs/clinical_epidemiology/oxford.asp. (Accessed March 16, 2020).

13. VanderWeele TJ, Ding P. Sensitivity Analysis in Observational Research: Introducing the E-Value. Ann Intern Med. 2017;167(4):268-74. doi 10.7326/M16-2607.

14. Yoon JH, Dammann R, Pfeifer GP. Hypermethylation of the $\mathrm{CpG}$ island of the RASSF1A gene in ovarian and renal cell carcinomas. International journal of cancer. 2001;94(2):212-7. doi 10.1002/ijc.1466.

15. Dreijerink K, Braga E, Kuzmin I, Geil L, Duh FM, Angeloni D, et al. The candidate tumor suppressor gene, RASSF1A, from human chromosome 3p21.3 is involved in kidney tumorigenesis. Proc Natl Acad Sci USA. 2001;98(13):75049. doi 10.1073/pnas.131216298.

16. Morrissey C, Martinez A, Zatyka M, Agathanggelou A, Honorio S, Astuti D, et al. Epigenetic inactivation of the RASSF1A 3p21.3 tumor suppressor gene in both clear cell and papillary renal cell carcinoma. Cancer research. 2001;61(19):7277-81.

17. Cairns P. Detection of promoter hypermethylation of tumor suppressor genes in urine from kidney cancer patients. Ann N Y Acad Sci. 2004;1022:40-3. doi 10.1196/annals.1318.007.

18. Gonzalgo ML, Yegnasubramanian S, Yan G, Rogers CG, Nicol TL, Nelson WG, et al. Molecular profiling and classification of sporadic renal cell carcinoma by quantitative methylation analysis. Clinical cancer research: an official journal of the American Association for Cancer Research. 2004;10(21):7276-83. doi 10.1158/1078 0432.CCR-03-0692.

19. Loginov VI, Maliukova AV, Seregin lu A, Khodyrev DS, Kazubskaia TP, Ermilova VD, et al. [Methylation of the promoter region of the RASSF1A gene, a candidate tumor suppressor, in primary epithelial tumors]. Mol Biol. 2004;38(4):654-67.

20. Tokinaga K, Okuda H, Nomura A, Ashida S, Furihata M, Shuin T. Hypermethylation of the RASSF1A tumor suppressor gene in Japanese clear cell renal cell carcinoma. Oncol Rep. 2004;12(4):805-10.

21. Dulaimi E, Ibanez de Caceres I, Uzzo RG, Al-Saleem T, Greenberg RE, Polascik TJ, et al. Promoter hypermethylation profile of kidney cancer. Clinical cancer research: an official journal of the American Association for Cancer Research. 2004;10(12 Pt 1):3972-9. doi 10.1158/1078 - 0432.CCR-04-0175.

22. Peters I, Rehmet K, Wilke N, Kuczyk MA, Hennenlotter J, Eilers T, et al. RASSF1A promoter methylation and expression analysis in normal and neoplastic kidney indicates a role in early tumorigenesis. Mol Cancer. 2007;6:49. doi 10.1186/1476-4598-6-49.

23. Costa VL, Henrique R, Ribeiro FR, Pinto M, Oliveira J, Lobo F, et al. Quantitative promoter methylation analysis of multiple cancer-related genes in renal cell tumors. BMC Cancer. 2007;7:133. doi 10.1186/1471-2407-7-133.

24. Gumz ML, Zou H, Kreinest PA, Childs AC, Belmonte LS, LeGrand SN, et al. Secreted frizzled-related protein 1 loss contributes to tumor phenotype of clear cell renal cell carcinoma. Clinical cancer research: an official journal of the 
American Association for Cancer Research. 2007;13(16):4740-9. doi 10.1158/1078 - 0432.CCR-07-0143.

25. Awakura Y, Nakamura E, Ito N, Kamoto T, Ogawa O. Methylation-associated silencing of SFRP1 in renal cell carcinoma. Oncol Rep. 2008;20(5):1257-63.

26. Onay H, Pehlivan S, Koyuncuoglu M, Kirkali Z, Ozkinay F. Multigene methylation analysis of conventional renal cell carcinoma. Urologia internationalis. 2009;83(1):107-12. doi 10.1159/000224878.

27. Ellinger J, Holl D, Nuhn P, Kahl P, Haseke N, Staehler M, et al. DNA hypermethylation in papillary renal cell carcinoma. BJU Int. 2011;107(4):664-9. doi 10.1111/j.1464-410X.2010.09468.x.

28. Atschekzei F, Hennenlotter J, Janisch S, Grosshennig A, Trankenschuh W, Waalkes S, et al. SFRP1 CpG island methylation locus is associated with renal cell cancer susceptibility and disease recurrence. Epigenetics. 2012;7(5):447-57. doi 10.4161/epi.19614.

29. Zheng FF, Chen EJ, Li XF, Deng CH, Dai YP, Qiu SP. [Abnormal methylation of Tim-3 gene in renal carcinoma]. J Contemp Urol Reprod Oncol. 2011;3(6):352-5.

30. Yin FC, Li F, Liu L, Cao H, Li HR, Sun S. C. [Detection and clinical significance of methylation in the promoter region of SFRP1 and SFRP2 genes in renal clear cell carcinoma]. J Hebei Med Univ. 2018;39(3):267-71.

31. Yin FC, Zhang AL, Tian JH. [Aberrant promoter methylation of SFRPs-the antagonists of Wnt in renal cell carcinoma]. Hebei Medical University 2010:13.

32. Liu B, Zhang AL, Zhao ZH, Ni XC. [The relationship between the methylation status of E-cadherin gene and $\beta$-catenin expression in renal cell carcinoma]. Mod Oncol. 2015;23(21):3122-27.

33. Zhang JY, Xiao XH, Liu B. [Methylation status of RASSF1A and BLU in bladder and kidney cancers]. Zhejiang Clin Med J. 2008;10(11):1418-20.

34. Duan JM, Li Z, Zhao M, Zhang JY, Peng B, Huang JH. [Abnormal methylation of RASSF1A and BLU genes in renal carcinoma]. Academic Journal of Second Military Medical University. 2007;28(10):1068-71.

35. Yu GS, Lai CY, Xu Y, Bu CF, Su ZX. Aberrant Methylation of RASSF1A gene Contribute to the Risk of Renal Cell Carcinoma: a Meta-Analysis. Asian Pacific journal of cancer prevention: APJCP. 2015;16(11):4665-9. doi 10.7314/apjcp.2015.16.11.4665.

36. Huang YQ, Guan H, Liu CH, Liu DC, Xu B, Jiang L, et al Association between RASSF1A promoter methylation and renal cell cancer susceptibility: a meta-analysis. Genetics molecular research: GMR 2016;15(2) doi 10.4238/gmr.15026994.

37. Hesson LB, Cooper WN, Latif F. The role of RASSF1A methylation in cancer. Disease markers. 2007;23(1-2):73-87. doi 10.1155/2007/291538.

38. Caldwell GM, Jones C, Gensberg K, Jan S, Hardy RG, Byrd P, et al. The Wnt antagonist sFRP1 in colorectal tumorigenesis. Cancer research. 2004;64(3):883-8. doi 10.1158/0008-5472.can-03-1346.

39. Katoh M. WNT signaling in stem cell biology and regenerative medicine. Curr Drug Targets. 2008;9(7):565-70. doi $10.2174 / 138945008784911750$.

40. Dahl E, Wiesmann F, Woenckhaus M, Stoehr R, Wild PJ, Veeck J, et al. Frequent loss of SFRP1 expression in multiple human solid tumours: association with aberrant promoter methylation in renal cell carcinoma. Oncogene. 2007;26(38):5680-91. doi 10.1038/sj.onc.1210345.

41. Mcllwain CC, Townsend DM, Tew KD. Glutathione S-transferase polymorphisms: cancer incidence and therapy. Oncogene. 2006;25(11):1639-48. doi 10.1038/sj.onc.1209373.

42. Dang DT, Chen F, Kohli M, Rago C, Cummins JM, Dang LH. Glutathione S-transferase pi1 promotes tumorigenicity in HCT116 human colon cancer cells. Cancer research. 2005;65(20):9485-94. doi 10.1158/0008-5472.CAN-05-1930. 


\section{Figures}

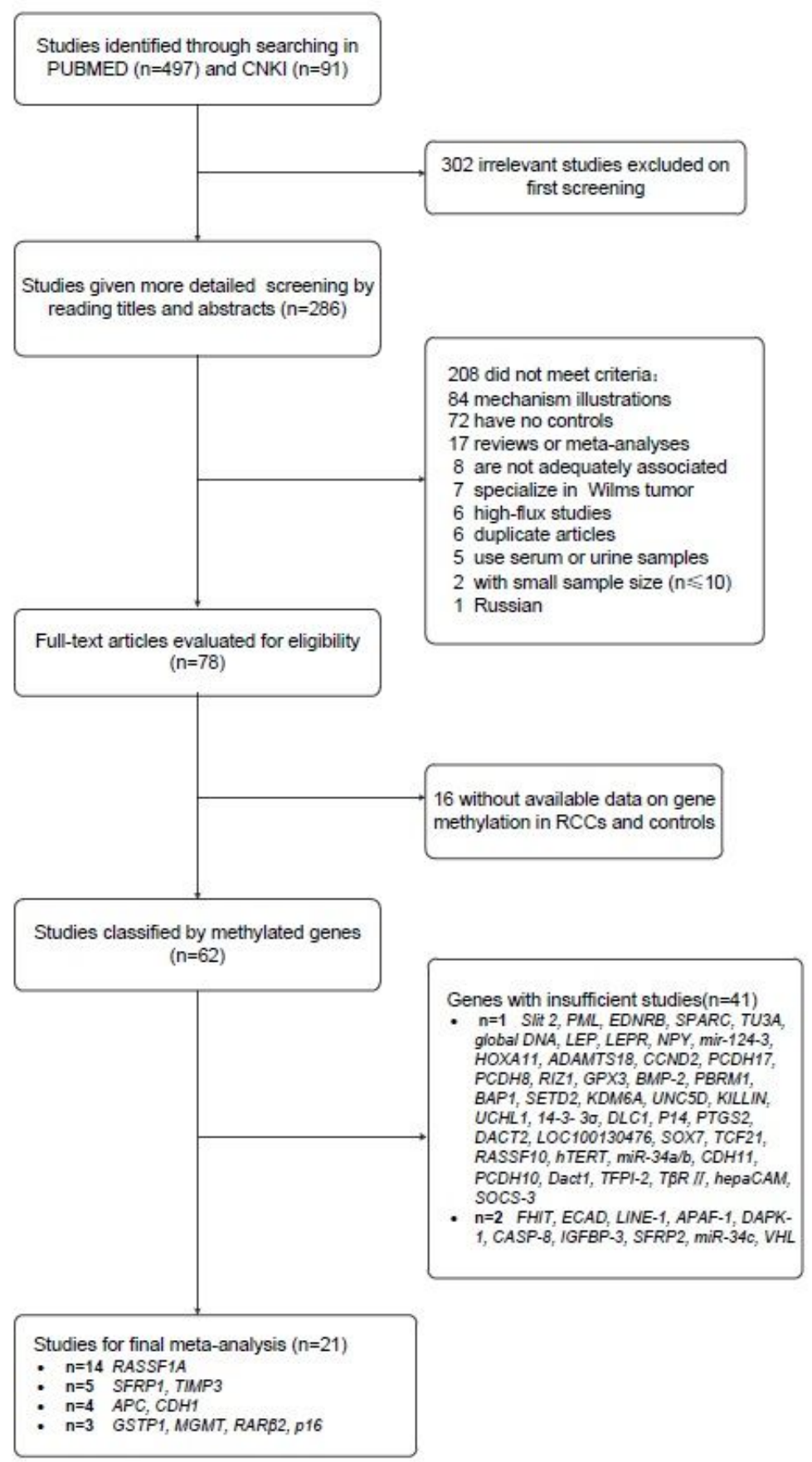

\section{Figure 1}

Flow chart of literature search and selection. 


\begin{tabular}{|c|c|c|c|c|c|c|c|}
\hline \multirow[b]{2}{*}{ Study } & & \multirow[b]{2}{*}{ OR } & \multicolumn{2}{|c|}{$95 \% \mathrm{Cl}$} & \multirow[b]{2}{*}{ p-Value } & \multirow[b]{2}{*}{$\mathrm{OR}$ and $95 \% \mathrm{Cl}$} & \multirow[b]{2}{*}{ Weight $\%$} \\
\hline & & & $\begin{array}{l}\text { Lower } \\
\text { limit }\end{array}$ & $\begin{array}{l}\text { Upper } \\
\text { limit }\end{array}$ & & & \\
\hline \multirow{14}{*}{ RASSF1A } & Onay H, 2009 & 3.250 & 0.818 & 11.509 & 0.068 & & 8.87 \\
\hline & Loginov VI, 2004 & 33.333 & 8.298 & 133.897 & 0.000 & 1 & 8.70 \\
\hline & Morrissey C, 2001 & 15.138 & 3.603 & 63.600 & 0.000 & I & 8.64 \\
\hline & Dreijerink K, 2001 & 131.625 & 22.480 & 770.345 & 0.000 & 1 & 8.15 \\
\hline & Gonzalgo ML, 2004 & 1.400 & 0.182 & 10.791 & 0.747 & & 7.71 \\
\hline & Tokinaga K, 2004 & 0.093 & 0.011 & 0.758 & 0.027 & & 7.63 \\
\hline & Peters I, 2007 & 1.000 & 0.081 & 16.496 & 1.000 & & 6.50 \\
\hline & Costa VL, 2007 & 0.029 & 0.002 & 0.492 & 0.014 & i & 6.45 \\
\hline & Dulaimi E, 2004 & 19.268 & 1.097 & 338.495 & 0.043 & & 6.40 \\
\hline & Caims P. 2004 & 21.894 & 1.213 & 395.094 & 0.037 & & 6.38 \\
\hline & Duan JM, 2007 & 97.632 & 5.334 & 1787.174 & 0.002 & & 6.34 \\
\hline & Yoon JH, 2001 & 26.793 & 1.446 & 496.349 & 0.027 & & 6.32 \\
\hline & Zhang JY, 2008 & 47.222 & 2.239 & 996.023 & 0.013 & I & 6.12 \\
\hline & Ellinger J, 2011 & 6.724 & 0.258 & 175.145 & 0.252 & & 5.81 \\
\hline Sub-total & $(F=78.11 \%, P<0.001)$ & 6.612 & 1.926 & 22.697 & 0.003 & & \\
\hline \multirow[t]{5}{*}{ SFRP1 } & Atschekzei F, 2012 & 1.320 & 1.185 & 1.470 & 0.000 & & 28.60 \\
\hline & Yin FC, 2018 & 2.448 & 1.301 & 4.805 & 0.008 & & 25.23 \\
\hline & Yin FC, 2010 & 7.933 & 3.007 & 20.831 & 0.000 & 1 & 21.66 \\
\hline & Awakura Y, 2008 & 7.568 & 1.632 & 35.096 & 0.010 & & 15.82 \\
\hline & Gumz ML, 2007 & 36.000 & 2.721 & 476.276 & 0.007 & & 8.68 \\
\hline Sub-total & $(F=85.26 \%, P<0.001)$ & 3.995 & 1.607 & 9.934 & 0.003 & & \\
\hline \multirow[t]{5}{*}{ TIMP3 } & Costa VL, 2007 & 0.657 & 0.285 & 1.512 & 0.323 & & 33.36 \\
\hline & Onay H, 2009 & 2.969 & 0.506 & 17.421 & 0.228 & & 23.98 \\
\hline & Dulaimi E, 2004 & 31.080 & 1.767 & 546.587 & 0.018 & & 15.11 \\
\hline & Zheng FF, 2011 & 8.474 & 0.387 & 185.348 & 0.175 & & 13.81 \\
\hline & Ellinger J, 2011 & 2.541 & 0.115 & 58.253 & 0.555 & & 13.74 \\
\hline Sub-total & $\left(F^{F}=58.80 \%, P=0.046\right)$ & 2.896 & 0.685 & 12.240 & 0.148 & & \\
\hline \multirow[t]{4}{*}{$A P C$} & Costa VL, 2007 & 2.390 & 0.802 & 7.126 & 0.118 & & 67.41 \\
\hline & Onay H, $200 \theta$ & 2.105 & 0.176 & 25.170 & 0.556 & & 13.06 \\
\hline & Ellinger J, 2011 & 0.452 & 0.026 & 7.751 & 0.584 & & 8.85 \\
\hline & Dulaimi E, 2004 & 3.261 & 0.180 & 59.200 & 0.424 & & 8.57 \\
\hline Sub-total & $(F=0.00 \%, P=0.738)$ & 2.052 & 0.837 & 5.031 & 0.116 & & \\
\hline \multirow[t]{4}{*}{$\mathrm{CDH} 1$} & Costa VL, 2007 & 0.381 & 0.155 & 0.835 & 0.035 & & 29.84 \\
\hline & Liu B, 2015 & 10.893 & 4.379 & 27.101 & 0.000 & & 29.80 \\
\hline & Dulaimi E, 2004 & 2.963 & 0.182 & 54.039 & 0.463 & & 20.32 \\
\hline & Ellinger J, 2011 & 6.200 & 0.321 & 119.795 & 0.227 & & 20.04 \\
\hline Sub-total & $\left(R^{2}=88.89 \%, P<0.001\right)$ & 2.745 & 0.303 & 24.873 & 0.369 & & \\
\hline \multirow[t]{3}{*}{ GSTP1 } & Ellinger J, 2011 & 3.920 & 0.436 & 35.204 & 0.223 & & 46.81 \\
\hline & Dulaimi E, 2004 & 2.673 & 0.146 & 48.004 & 0.508 & & 26.65 \\
\hline & Costa VL, 2007 & 9.752 & 0.529 & 179.911 & 0.126 & & 26.54 \\
\hline Sub-total & $(F=0.00 \%, P=0.815)$ & 4.508 & 1.004 & 20.239 & 0.049 & & \\
\hline \multirow[t]{3}{*}{ MGMT } & Onay $\mathrm{H}, 2000$ & 1.875 & 0.385 & 9.120 & 0.436 & & 41.56 \\
\hline & Costa VL, 2007 & 0.108 & 0.013 & 0.888 & $0.03 \theta$ & & 33.91 \\
\hline & Dulaimi E, 2004 & 1.578 & 0.083 & 30.056 & 0.762 & & 24.53 \\
\hline Sub-total & $(F=58.21 \%, P=0.091)$ & 0.679 & 0.099 & 4.650 & 0.693 & & \\
\hline \multirow[t]{3}{*}{ RAR $\beta 2$} & Onay H, 2009 & 0.632 & 0.084 & 4.230 & 0.636 & & 56.19 \\
\hline & Dulaimi E, 2004 & 3.261 & 0.180 & 59.200 & 0.424 & & 24.18 \\
\hline & Costa VL, 2007 & 2.517 & 0.101 & 62.878 & 0.574 & & 19.62 \\
\hline Sub-total & $(R=0.00 \%, P=0.578)$ & 1.232 & 0.296 & 5.126 & 0.774 & & \\
\hline \multirow[t]{3}{*}{$p 16$} & Onay H, 2000 & 2.273 & 0.634 & 8.146 & 0.208 & & 71.37 \\
\hline & Costa VL, 2007 & 0.829 & 0.051 & 13.498 & 0.895 & & 14.94 \\
\hline & Dulaimi E, 2004 & 2.389 & 0.129 & 44.093 & 0.558 & & 13.69 \\
\hline Sub-total & $(F=0.00 \%, P=0.805)$ & 1.968 & 0.669 & 5.787 & 0.218 & & \\
\hline & & & & & & 0.1 & \\
\hline
\end{tabular}

Figure 2

Forest plots of the associations between TSGs methylation and RCC risk. 


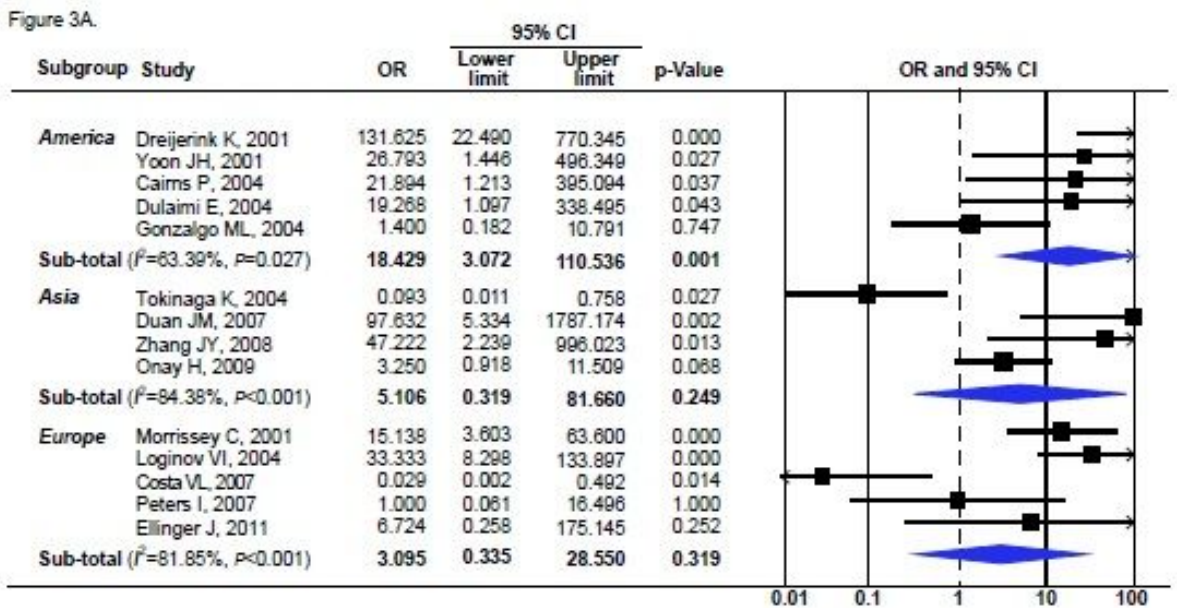

Figure 3B.

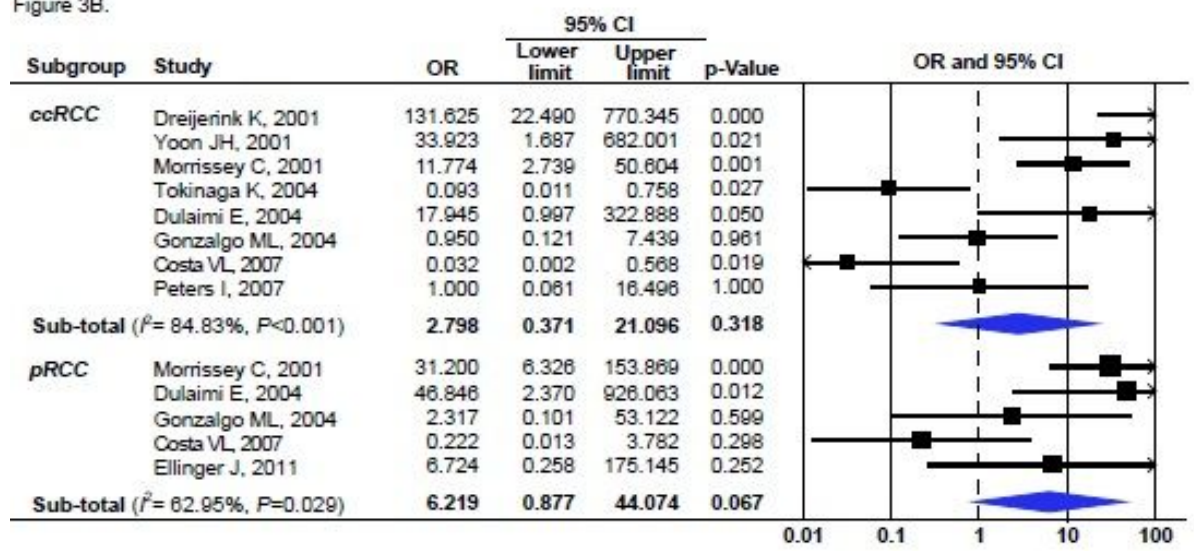

igure $3 \mathrm{C}$.

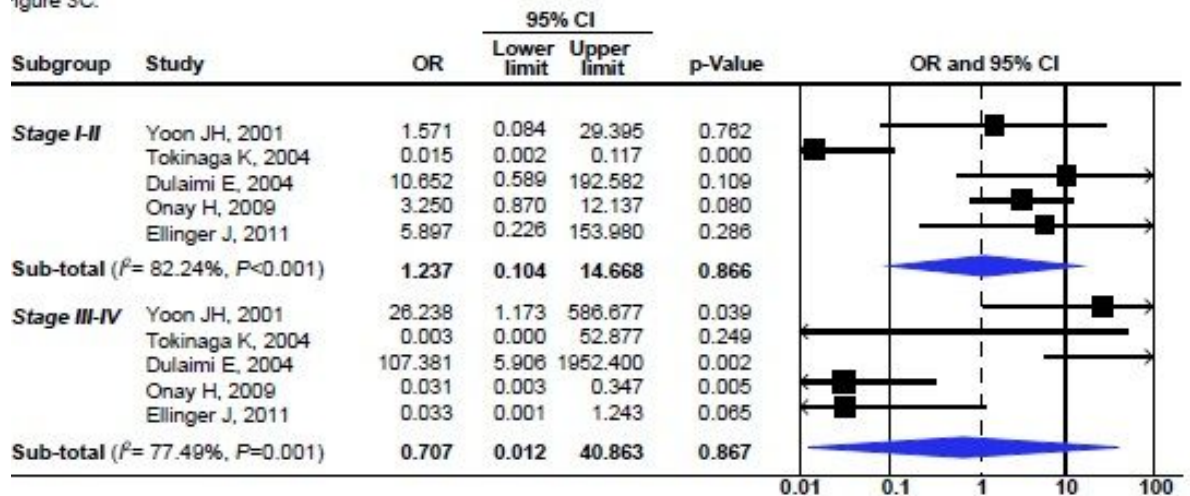

\section{Figure 3}

Subgroup analyses for the associations of RASSF1A methylation and RCC risk by (A) Population regions, (B) Pathological subtypes or (C) Clinical stages of cases.

\section{Supplementary Files}

This is a list of supplementary files associated with this preprint. Click to download.

- 3Supplementarylnformation.docx

- 5PRISMAChecklist.docx 